University of Wollongong

Research Online

Faculty of Engineering and Information

Faculty of Engineering and Information

Sciences - Papers: Part A

Sciences

$1-1-2016$

\title{
Axial load-axial deformation behaviour of circular concrete columns reinforced with GFRP bars and helices
}

Hogr Karim

University of Wollongong, hmjkk643@uowmail.edu.au

M Neaz Sheikh

University of Wollongong, msheikh@uow.edu.au

Muhammad N. S Hadi

University of Wollongong, mhadi@uow.edu.au

Follow this and additional works at: https://ro.uow.edu.au/eispapers

Part of the Engineering Commons, and the Science and Technology Studies Commons

Research Online is the open access institutional repository for the University of Wollongong. For further information contact the UOW Library: research-pubs@uow.edu.au 


\title{
Axial load-axial deformation behaviour of circular concrete columns reinforced with GFRP bars and helices
}

\author{
Abstract \\ Fibre Reinforced Polymer (FRP) bars has attracted a significant amount of research attention in the last \\ three decades to overcome the problems associated with the corrosion of steel reinforcing bars in \\ reinforced concrete members. A limited number of studies, however, have investigated the behaviour of \\ concrete columns reinforced with FRP bars. Also, available design standards either ignore the \\ contribution of or do not recommend the use of GFRP bars in compression members. This study reports \\ the results of experimental investigations of concrete specimens reinforced with GFRP bars and GFRP \\ helices as longitudinal and transverse reinforcement, respectively. A total of five circular concrete \\ columns of $205 \mathrm{~mm}$ in diameter and $800 \mathrm{~mm}$ in height were cast and tested under axial compression. \\ The experimental results showed that reducing the spacing of the GFRP helices or confining the \\ specimens with CFRP sheet led to improvements in the strength and ductility of the specimens. Also, an \\ analytical model has been developed for the axial load-axial deformation behaviour of the circular \\ concrete columns reinforced with GFRP bars and helices. The model has been validated with the \\ experimental results.

\section{Disciplines} \\ Engineering | Science and Technology Studies

\section{Publication Details} \\ Karim, H., Sheikh, M. Neaz. \& Hadi, M. N. S. (2016). Axial load-axial deformation behaviour of circular \\ concrete columns reinforced with GFRP bars and helices. Construction and Building Materials, 112 \\ $1147-1157$.
}




\title{
Axial Load-Axial Deformation Behaviour of Circular Concrete Columns Reinforced with GFRP Bars and Helices
}

\author{
Hogr Karim ${ }^{1}$ \\ ${ }^{1}$ Ph.D. Candidate, School of Civil, Mining, and Environmental Engineering, University of \\ Wollongong, Australia. Email: hmjkk643@uowmail.edu.au \\ M. Neaz Sheikh ${ }^{2}$
}

${ }^{2}$ Senior Lecturer, School of School of Civil, Mining, and Environmental Engineering, University of Wollongong, Australia. Email: msheikh@uow.edu.au Muhammad N. S. Hadi ${ }^{3, *}$

${ }^{3}$ Associate Professor, School of School of Civil, Mining, and Environmental Engineering, University of Wollongong, Australia. Email: mhadi@uow.edu.au , ${ }^{*}$ Corresponding author

Fibre Reinforced Polymer (FRP) bars has attracted a significant amount of research attention in the last three decades to overcome the problems associated with the corrosion of steel reinforcing bars in reinforced concrete members. A limited number of studies, however, have investigated the behaviour of concrete columns reinforced with FRP bars. Also, available design standards either ignore the contribution of or do not recommend the use of GFRP bars in compression members. This study reports the results of experimental investigations of concrete specimens reinforced with GFRP bars and GFRP helices as longitudinal and transverse reinforcement, respectively. A total of five circular concrete columns of $205 \mathrm{~mm}$ in diameter and $800 \mathrm{~mm}$ in height were cast and tested under axial compression. The experimental results showed that reducing the spacing of the GFRP helices or confining the specimens with CFRP sheet led to improvements in the strength and ductility of the specimens. Also, an analytical model has been developed for the axial load-axial 
deformation behaviour of the circular concrete columns reinforced with GFRP bars and helices. The model has been validated with the experimental results.

Keywords: Reinforced concrete, Column, Concentric load, GFRP bars, CFRP wrapping

\section{Introduction}

Fibre reinforced polymer (FRP) composite material in the construction of new structures and retrofitting of existing structures is a noble invention which has the potential to replace the conventional steel bars and plates, as FRP can overcome the problems associated with corrosion of reinforcing bars [1]. Corrosion of steel reinforcement is a considerable issue in humid and aggressive areas and causes large maintenance cost and the loss of the performance of structural components [2, 3]. Different methods such as the use of galvanised or stainless steel bars, epoxy coating and cathodic protection have been used to protect reinforcement from corrosion [4-7]. None of the methods, however, have fully eliminated the corrosion of steel reinforcement $[8,9]$.

Despite having relatively greater tensile strength of FRP bars in comparison with steel bars, steel bars cannot be replaced with the same amount of FRP bars [10]. This is because FRP bars are anisotropic and the modulus of elasticity of FRP bars is smaller than the modulus of elasticity of steel bars. Moreover, the stress-strain behaviour of FRP bars is linear elastic until failure [11, 12]. Few experimental studies were conducted to investigate the influence of replacing steel bars with FRP bars on the behaviour of square and circular concrete columns under concentric loads [13-18]. It was reported that the load carrying capacity of the GFRP Reinforced Concrete (RC) columns is about 13 to $16 \%$ smaller than the load carrying capacity of corresponding steel-RC columns. Also, the contribution of the GFRP longitudinal bars is about 3 to $10 \%$ of the total load carrying capacity of columns compared to 12 to $16 \%$ contribution of the same amount of steel bars. However, circular 
RC columns with GFRP helices and with the same amount (volumetric ratio) of steel helices can achieve similar confined concrete core strength and ductility.

Over the last three decades extensive studies have been conducted on the confinement of concrete columns with FRP sheets [19-29]. The experimental results revealed that confining concrete columns with FRP sheets can considerably improve the strength and ductility of concrete columns. This improvement in strength and ductility is because confinement restrains the lateral dilation of the concrete columns and holds the concrete core. Therefore, the confined concrete can carry more loads and undergo larger axial deformations until the rupture of the confining material. FRP wrapping can also act as a barrier to protect the concrete core against harsh and aggressive environments.

It has been observed in a comprehensive literature review that most of the previous studies focused on the effects of replacing steel bars with GFRP bars and investigated the contribution of GFRP bars in the load carrying capacity of the columns. A limited number of studies discussed the effects of GFRP bars and GFRP helices on the confinement of concrete core and ductility. Moreover, analytical studies on the behaviour of concrete columns reinforced with GFRP bars and helices are very limited. Tobbi et al. [30] proposed two set of equations to predict the ultimate confined concrete strength and the corresponding strain for confined square concrete columns with different GFRP and CFRP tie configurations based on the test results of 23 square columns under concentric loads. However, there is no empirical equation to predict the strength of circular columns confined with GFRP helices. It is noted that available models to predict the ultimate confined concrete strength and the corresponding strain for confined concrete with steel helices cannot be directly used for confined concrete with GFRP helices because of the differences in the mechanical properties of GFRP and steel. In this study, a total of five circular concrete column specimens were 
tested under concentric axial loads to investigate the axial compressive behaviour of the specimens. The specimens were reinforced with either GFRP bars and GFRP helices or only GFRP helices. One of the specimens reinforced with GFRP bars and helices was externally confined with CFRP sheets. The confinement conditions and the axial load-axial deformation behaviour of the specimens were investigated. Also, an analytical model has been developed which can well simulate the axial load-axial deformation behaviour of circular concrete columns reinforced with GFRP bars and helices.

\section{Experimental program}

\subsection{Configuration of specimens}

The GFRP bars and helices used in this study had a sand-coated surface to enhance the bond between the bars and the surrounding concrete. The GFRP bars and helices were provided by VRod Australia [31]. Sand coated \#4 (nominal diameter=12.7 mm) GFRP bars were used for longitudinal reinforcement and sand coated \#3 (nominal diameter $=9.5 \mathrm{~mm}$ ) GFRP helices were used for transverse reinforcement. One of the specimens was confined with CFRP sheets to investigate the influence of CFRP wrapping on the strength and ductility of the specimens. The CFRP sheet was $75 \mathrm{~mm}$ wide with a unidirectional fibre density of $340 \mathrm{~g} / \mathrm{m}^{2}$ and thickness of 0.45 $\mathrm{mm}$. One specimen was wrapped with two layers of CFRP sheets with a total thickness of $0.9 \mathrm{~mm}$. Also, an overlap length of $100 \mathrm{~mm}$ was maintained to prevent debonding of the CFRP wrapping.

A total of five circular RC column specimens were cast and tested under monotonic axial compression. The specimens were $205 \mathrm{~mm}$ in diameter and $800 \mathrm{~mm}$ in height. The dimensions were chosen to be suitable to the condition and capacity of the available testing facility in the laboratory. All the specimens were cast on the same day with ready mix concrete. The design compressive strength of concrete was $32 \mathrm{MPa}$. The maximum size of the coarse aggregate for the concrete was 
$10 \mathrm{~mm}$. Table 1 provides dimensions, reinforcement schemes and configurations of the tested specimens. The specimens were identified by the longitudinal reinforcement material and its number and the transversal reinforcement material and its spacing. For example, Specimen G6-G60 is reinforced longitudinally with six GFRP bars and transversally with GFRP helix at $60 \mathrm{~mm}$ pitch. Specimen 00-G30 is reinforced only transversally with GFRP helices at $30 \mathrm{~mm}$ pitch.

\subsection{Preparation and casting of specimens}

The formwork used for casting the concrete specimens was PVC pipe. The longitudinal GFRP bars were cut to $760 \mathrm{~mm}$ in order to have $20 \mathrm{~mm}$ clear cover at the top and bottom of the reinforcement cage. The GFRP helices were manufactured in a coil shape with $170 \mathrm{~mm}$ outer diameter by the manufacturer [31]. The concrete clear side cover was $17.5 \mathrm{~mm}$ for all the specimens. The PVC moulds were fixed vertically in a wooden formwork and the reinforcement cages were inserted into the PVC moulds. Concrete was placed into the formwork in three stages. In every stage concrete was vibrated using an electric vibrator to compact and to remove air bubbles. The specimens were cured by covering with wet hessian and plastic sheets after 24 hours of casting to maintain the moisture conditions. The curing process lasted 28 days before testing. After curing, the surface of Specimen CG6-G60 was cleaned and grinded to prepare for wrapping with two layers of CFRP sheets in the hoop direction by using wet layup technique. A mixture of epoxy resin and hardener at a ratio of 5:1 was used as a bonding agent. An overlap length of $100 \mathrm{~mm}$ was applied in the hoop direction to maintain sufficient bonding strength. Afterwards, the wrapped specimen was placed in room temperature for 14 days to harden and cure the epoxy.

\subsection{Preliminary test}

The compressive strength of the concrete was found by testing concrete cylinders of $100 \mathrm{~mm}$ in diameter and $200 \mathrm{~mm}$ in height according to AS 1012.9-1999 [32]. The average 28-day 
compressive strength of the concrete was $37 \mathrm{MPa}$. The ultimate tensile strength and the corresponding strain and modulus of elasticity of the GFRP bars were determined by testing five pieces for each of the two diameter $(12.7$ and $9.5 \mathrm{~mm})$ bars with a test length of 40 times the diameter of the bars plus the required gripping length at both ends, as recommended by ASTM D7205-11 [33]. The test results are reported in Table 2. The mechanical properties of the CFRP sheets were found by coupon test as recommended in ASTM D7565-10 [34]. Five samples of two layers of CFRP sheets with $25 \mathrm{~mm}$ width and $250 \mathrm{~mm}$ length were taken. The average maximum tensile load and the corresponding strain were $1125 \mathrm{~N} / \mathrm{mm}$ and $0.0147 \mathrm{~mm} / \mathrm{mm}$, respectively. Also, the tensile modulus of elasticity was $85 \mathrm{GPa}$.

\subsection{Instrumentation and testing of specimens}

The specimens were instrumented internally and externally to capture the axial deformation of the specimens and strains in the reinforcement. The axial deformation of the specimens was recorded by two Linear Variable Differential Transducers (LVDT) attached vertically to the testing machine in the two opposite corners. Also, before casting the concrete, two electrical strain gages were attached at the mid-height of the two opposite longitudinal bars in order to capture the axial strain at these bars. In addition, two electrical strain gages were attached at mid-height of the two opposite sides of the helical reinforcement to measure the strain in the hoop direction. For the confined specimens with CFRP sheets, two electrical strain gages were also attached at mid-height of two opposite sides of the CFRP wrap to measure the strain in the hoop direction.

All specimens were tested in the laboratories of the School of Civil, Mining and Environmental Engineering at the University of Wollongong, Australia. The Denison $5000 \mathrm{kN}$ compression testing machine was used to test the specimens. The top and bottom of the specimens were wrapped by a single layer of CFRP sheet to prevent premature failure of the concrete during axial compression 
tests. The width of CFRP sheet was $75 \mathrm{~mm}$. Also, both ends of the specimens were capped with high strength plaster to distribute the load uniformly. The test stared with a force-controlled preloading the specimens at a rate of $2 \mathrm{kN} / \mathrm{s}$ to about $10 \%$ of the yield loads of the specimens and then unloaded to $20 \mathrm{kN}$. Afterwards, the test resumed with displacement control loading $(0.005 \mathrm{~mm} / \mathrm{s})$ until the resistance of the tested specimen dropped to $30 \%$ of the yield load or until the axial displacement reached $40 \mathrm{~mm}$. The applied axial load and displacement of the tested specimens were recorded through the internal load cell of the Denison testing machine. Also, the experimental test results of the axial deformations and axial and hoop strains were recorded through the LVDTs and the strain gages. The applied loads were also recorded through a sensor located on the bottom of the testing machine. The LVDTs, strain gages and the sensor were connected to a data-logger to record the readings at every 2 seconds.

\section{Experimental results and observations}

\subsection{Failure modes}

All the specimens were tested under axial monotonic load until failure. The vertical hairline cracks appeared at around $90 \%$ of the first peak loads in the specimens that were only confined with the GFRP helices. With the increase of the applied axial load, cracks propagated and caused spalling of the concrete cover, which reduced the axial load carrying capacity of the specimens. Afterwards, cracks initiated in the concrete core which dilate the concrete core and produced stresses in the confining materials (GFRP helices and CFRP sheets). The produced stresses in the confining materials held the concrete core and provided enough stiffness to carry sustained loads without failure. With the increasing applied load, the hoop strain in the confining materials increased until rupture occurred. The rupture of the confining material led to fracture of the longitudinal GFRP bars, crushing of concrete core and complete failure of the specimens. Figure 1 shows failure modes of the tested specimens. 


\subsection{Axial load-axial deformation behaviour}

Figure 2 shows the axial load-axial deformation behaviour of the tested specimens. In general, the ascending part of the load-deformation curve of the specimens was similar until first peak load because the ascending part was dominated mainly by the concrete strength. Afterwards, the specimens that were only confined with GFRP helices exhibited a decrease in the load carrying capacity with the increase of a small amount of the axial deformation because of the spalling of concrete cover. After the first axial peak load, cracks were initiated in the concrete core that led to dilation of the concrete core. Dilation of the concrete core produced stresses in the confining material because of the Poisson's effect. Therefore, the axial load-axial deformation behaviour of the specimens experienced a second ascending part. Hence, the second peak loads were greater than the first peak loads. However the second peak load of Specimen 00-G60 was smaller than the first peak load because the specimen was not reinforced with longitudinal reinforcement. Also, the pitch of the GFRP helix in 00-G60 was greater than the pitch of GFRP helix for Specimen 00-G30. Due to not having concrete cover in the confined specimen with CFRP sheets (CG6-G60) the transition between the first and second ascending parts of the load-deformation curve was a continuous smooth curve.

\subsection{Experimental results and discussion}

Table 3 reports the experimental results in terms of the first and second peak loads and the corresponding axial deformations and ductility. In this study, the ductility of the specimens is calculated as the ratio of the axial deformation corresponding to the second peak load to the axial deformation corresponding to the first peak load [35]. However, for the Specimen 00-G60, axial deformation corresponding to the second peak load was taken when the load dropped to $80 \%$ of the first peak load in the descending part. Also, for the Specimen CG6-G60, axial deformation 
corresponding to the transition point between the first and second ascending parts was taken as the deformation corresponding to the first peak load [36].

In general, the specimens with longitudinal GFRP bars performed better in comparison to the corresponding specimens without longitudinal bars in terms of load carrying capacity and ductility. The specimens with longitudinal GFRP bars achieved about $13 \%$ and 52\% greater first and second peak loads, respectively, than the corresponding specimens without longitudinal bars. Also, the contribution of the longitudinal GFRP bars in the first and second peak load carrying capacities of the specimens was about 11 and $23 \%$, respectively. The longitudinal GFRP bars considerably improved the ductility of the specimens with $60 \mathrm{~mm}$ pitch of GFRP helix, which may be because the longitudinal GFRP bars reduced the unconfined concrete areas between the helices and caused the concrete core to undergo a large axial deformation. However, the influence of the longitudinal GFRP bars in the improvement of the ductility in the specimens with $30 \mathrm{~mm}$ pitch of GFRP helix was not very significant. This may be because the smaller pitch of GFRP helix effectively confined the concrete core and the effect of longitudinal bars in confining the concrete core was not as significant. Reducing the pitch of the GFRP helices from 60 to $30 \mathrm{~mm}$ increased the first and second peak loads of the specimens by about $8 \%$ and $43 \%$, respectively. The lesser improvement of the first peak load was because the hoop strain in the GFRP helices was less than 5\% of the ultimate tensile strain, so the confinement was not considerably activated. Confining the specimens with CFRP sheet led to the increase of the second peak loads by $115 \%$. Also, the ductility of the specimens improved considerably by reducing the pitch of GFRP helices and externally confining the specimens with CFRP sheets.

The confined concrete strength of the tested specimens was calculated by subtracting the loads carried by the longitudinal bars from the second peak load of the specimens and dividing it by the 
area of confined concrete core. The experimental results of the confined concrete strength are reported in Table 4. It can be observed that specimens with longitudinal GFRP bars obtained a greater confined concrete strength than the corresponding specimens without longitudinal GFRP bars. This may be because the longitudinal bars can reduce the area of unconfined concrete between the helices pitch and increase the hoop strain at the confining materials. The ratio of hoop rupture strain to the ultimate tensile strain of the GFRP helices was about 0.33 and 0.25 in the specimens with and without longitudinal GFRP bars, respectively. Also, the hoop rupture strain of the CFRP sheet was about 0.75 of its ultimate tensile strain.

\section{Analytical modelling}

The specimens tested in this study can be broadly divided into three components: (i) longitudinal GFRP bars, (ii) unconfined concrete cover, and (iii) confined concrete core with GFRP helices. For the specimen confined with CFRP sheets (CG6-G60), the concrete cover was confined with CFRP sheets and the concrete core was confined with GFRP helices and CFRP sheets.

\subsection{Longitudinal GFRP bras}

Based on the experimental studies on GFRP bars $[11,12]$ the stress-strain behaviour of the bars is linear elastic until failure. Therefore, the axial stress of the longitudinal GFRP bars at different points can be represented by Eq. (1), by assuming that perfect bonding exists between the GFRP bar and the surrounding concrete. Also, it is assumed that the axial strain of the concrete and GFRP bars are equal at any point.

$$
f_{f b}=\varepsilon_{c} E_{f b}
$$

where $f_{f b}$ is the stress of the longitudinal GFRP bars, $\varepsilon_{c}$ is the axial strain of the concrete and $E_{f b}$ is the modulus of elasticity of the GFRP bars. 


\subsection{Unconfined concrete}

The stress-strain behaviour of unconfined concrete proposed by Yang et al. [37] has been adopted in this study to model the behaviour of unconfined concrete cover.

$$
\begin{gathered}
f_{c}=\frac{(\beta+1)\left(\frac{\varepsilon_{c}}{\varepsilon_{c o}}\right)}{\beta+\left(\frac{\varepsilon_{c}}{\varepsilon_{c o}}\right)^{\beta+1}} f_{c o} \\
\beta=0.20 \exp (0.73 \xi) \text { for } \varepsilon_{c} \leq \varepsilon_{c o} \\
\beta=0.41 \exp (0.77 \xi) \text { for } \varepsilon_{c}>\varepsilon_{c o} \\
\xi=\left(\frac{f_{c o}}{10}\right)^{0.67}\left(\frac{2300}{\omega_{c}}\right)^{1.17}
\end{gathered}
$$

where $\varepsilon_{c}$ is the axial concrete strain at any concrete stress $f_{c}, f_{c o}$ is the unconfined concrete strength which is equal to $85 \%$ of cylinder compressive strength $\left(f_{c}^{\prime}\right)$ at age 28 days, $\varepsilon_{c o}$ is the unconfined concrete strain corresponding to $f_{c o}$, and $\omega_{c}$ is the density of concrete which can be taken as 2400 $\mathrm{kg} / \mathrm{m}^{3}$ for normal-weight concrete. The elastic modulus $\left(E_{1}\right)$ and strain of unconfined concrete are calculated using Eq. (6) and (7) as proposed in ACI 318-14 [38] and Légeron [39], respectively.

$$
\begin{aligned}
& E_{1}=4730 \sqrt{f_{c o}} \quad(\mathrm{MPa}) \\
& \varepsilon_{c o}=0.0005 f_{c o}^{0.4} \quad(\mathrm{MPa})
\end{aligned}
$$

\subsection{Confined concrete}

Lateral confinement leads to the improvement in the strength and strain of concrete as the concrete core is restricted laterally. The peak strength and the corresponding axial strain can be calculated using Eq. (8) and (9), respectively, as proposed in Karim et al. [40].

$$
\begin{gathered}
f_{c c}=k_{c} f_{c o} \\
\varepsilon_{c c}=k_{c}{ }^{2} \varepsilon_{c o} \\
k_{c}=\frac{f_{c o}+5 f_{l}}{f_{c o}+0.5 f_{l}}
\end{gathered}
$$


where $k_{c}$ is the confinement coefficient factor and $\varepsilon_{c c}$ is the ultimate confined concrete strain corresponding to the peak confined concrete strength $f_{c c}$. $f_{l}$ is the lateral confining pressure that can be calculated using Eq. (12) and (13) for GFRP helices and CFRP sheets, respectively.

$$
\begin{gathered}
f_{l}=\frac{2 A_{h} k_{\varepsilon} f_{\text {fbent }}}{d_{c} s} \\
f_{l}=\frac{2 t_{f} k_{\varepsilon} f_{f u}}{D}
\end{gathered}
$$

where $A_{h}$ is the area of the GFRP helices, $k_{\varepsilon}$ is the ratio of the hoop rupture strain to the ultimate tensile strain of the confining materials, $f_{\text {fbent }}$ is the tensile strength of the bent GFRP bar or GFRP helix, $d_{c}$ is the diameter of the confined concrete core measured as the distance between the centre line of the GFRP helices, $s$ is the pitch of the GFRP helices, $t_{f}$ is the thickness of the CFRP sheet, $f_{f u}$ is the ultimate tensile strength of the CFRP sheet and $D$ is the diameter of the specimens. The value of $k_{\varepsilon}$ is recommended as 0.55 for the CFRP sheet according to ACI 440.2R-08 [41]. However, $k_{\varepsilon}=0.55$ underestimates the hoop rupture strain $[27,42,43]$. Therefore, $k_{\varepsilon}$ is calculated using Eq. (13) as proposed in Ozbakkaloglu and Lim [44].

$$
k_{\varepsilon}=0.9-2.3 f_{c o} \times 10^{-3}-0.75 E_{f} \times 10^{-6}
$$

where $E_{f}$ is the tensile modulus of elasticity of the CFRP sheet. The value of $k_{\varepsilon}$ for the GFRP helices is still under investigations. Hence, the experimentally recorded strain value for the GFRP helices was used in this study. The hoop rupture strain of the GFRP helices was about 33 and 25\% $\left(k_{\varepsilon}=0.33\right.$ and 0.25$)$ of the ultimate tensile strain of the GFRP bars for the specimens with and without longitudinal GFRP bars, respectively. The tensile strength of the bent GFRP bar or helix is lower than the ultimate tensile strength of the straight bars. As GFRP bar is not an isotropic material, different directions of the applied load leads to the reduction of the ultimate tensile strength of the GFRP bars [45]. The tensile strength of the GFRP helices can be calculated using Eq. (14) as recommended in ACI 440.1R-15 [46]. 


$$
f_{\text {fbent }}=\left(0.05 \frac{r_{b}}{d_{b}}+0.3\right) f_{f u} \leq f_{f u}
$$

where $r_{b}$ is the inner radius of the helices, $d_{b}$ is the diameter of the helices bars and $f_{f u}$ is the ultimate tensile strength of the GFRP bars.

For the specimen reinforced with GFRP helices and confined with CFRP sheets, the concrete cover is confined by CFRP sheet and concrete core is confined by GFRP helices and CFRP sheet as shown in Fig. 3. The confined concrete strength can be determined using Eq. (15) as recommended by different authors [47-49].

$$
f_{c c}=\frac{f_{c c, \text { cover }} A_{\text {cover }}+f_{c c, \text { core }} A_{\text {core }}}{A_{g}}
$$

where $f_{c c, \text { cover }}$ and $f_{c c, \text { core }}$ are the confined concrete strength of the concrete core and cover, respectively, and $A_{\text {cover }}$ and $A_{\text {core }}$ are the areas of concrete cover and core, respectively, and $A_{g}$ is the gross area of the concrete cross-section.

The stress-strain behaviour of confined concrete proposed by Samaan et al. [50] has been adopted in this study to model the behaviour of confined concrete core.

$$
\begin{gathered}
f_{c}=\frac{\left(E_{1}-E_{2}\right) \varepsilon_{c}}{\left[1+\left(\frac{\left(E_{1}-E_{2}\right) \varepsilon_{c}}{f_{o}}\right)^{n}\right]^{1 / n}}+E_{2} \varepsilon_{c} \\
E_{2}=\frac{f_{c c}-f_{o}}{\varepsilon_{c c}} \\
f_{o}=0.872 f_{c}^{\prime}+0.371 f_{l}+6.258 \\
n=1+\frac{1}{E_{1} / E_{2}-1}
\end{gathered}
$$

where $E_{2}$ is the slope of the second ascending part of axial stress-strain curve of confined concrete, $n$ is the curve-shaped parameter and $f_{o}$ is the intercept of the second slope with the stress axis. 


\section{Experimental versus analytical results}

\subsection{Curve-shaped parameter $(n)$}

Figure 4 shows the stress-strain behaviour of unconfined and confined concrete drawn using Eq. (2) and (16), respectively. It can be observed that the ascending part of the confined concrete is smaller than the unconfined concrete. It is evident that the differences are caused by inaccurate estimation of the curve-shaped parameter $(n)$ calculated using Eq. (19). In general, increasing the value of $n$ means the reduction of the radius of the transition curve that connects the first and second ascending parts of the confined concrete stress-strain curve. In order to estimate a reasonable value of $n$, it was assumed that the first ascending part of the stress-strain curve of unconfined and confined concrete are equal within the elastic limit range of the concrete core. This assumption is reasonable as concrete core within the elastic axial strain is not cracked and the lateral pressure is not considerably activated. The axial strain value at the end of the elastic limit state is assumed to be $0.5 \varepsilon_{c o}[51]$. From this assumption, Eq. (20) is proposed.

$$
f_{c, \text { unconf. }}=f_{c, \text { conf. }} . \text { for } \quad \varepsilon_{c} \leq 0.5 \varepsilon_{c o}
$$

where $f_{c, \text { unconf. }}$ and $f_{c, \text { conf }}$. are the unconfined and confined concrete stress, respectively, corresponding to $\varepsilon_{c}$. By substituting Eq. (16) in (20) and considering $\varepsilon_{c}=0.5 \varepsilon_{c o}$, the relationship between $n$ and other influencing parameters can be established in Eq. (21).

$$
\frac{E_{1}-E_{2}}{2 f_{c, 0.5} / \varepsilon_{c o}-E_{2}}=\left[1+\left(\frac{E_{1}-E_{2}}{2 f_{o} / \varepsilon_{c o}}\right)^{n}\right]^{1 / n}
$$

where $f_{c, 0.5}$ is the unconfined concrete stress corresponding to $0.5 \varepsilon_{c o}$. The $f_{c, 0.5}$ and $\varepsilon_{c o}$ can be expressed as a function of $E_{1}$ using Eq. (2), (6) and (7). Eventually, the value of $n$ is a function of $E_{1}, E_{2}$ and $f_{o}$. However, the relationship between $n$ and the parameters that affect $n$ is complex. Hence, a parametric study was conducted to estimate the relationship between $E_{1}, E_{2}$ and $f_{o}$ with $n$. An algorithm was written in MATLAB to numerically solve Eq. (21) with the change of the 
parameters within reasonable range to obtain a representative value of $n$. The flow chart of the algorithm is shown in Fig. 5.

\subsection{Influence of the concrete parameters on $n$}

Figure 6 shows the effects of $E_{1}$ on $n$ with fixed values of $E_{2}$ and $f_{o}$. In this study, the values of $E_{1}$ was considered to vary from 20,000 to $48,000 \mathrm{MPa}$ which correspond to $f_{c}^{\prime}$ between 20 to $100 \mathrm{MPa}$. Figure 7 shows the relationship between $E_{1}$ and $n$. It can be observed that the value of $n$ increased with increasing of $E_{1}$ because increasing the value of $E_{1}$ leads to the reduction of the radius of the transition curve between the first and second ascending parts of the confined stress-strain curve.

Figure 8 shows the effect of changing $E_{2}$ on $n$ with fixed values of $E_{1}$ and $f_{o}$. It is clear that the radius of the transition curve should be reduced with the increase in the value of $E_{2}$ in order to have the ascending part of the confined stress-strain curve the same as the ascending part of the unconfined concrete. To demonstrate the influence and relationship between $E_{2}$ and $n$, the values of $E_{2}$ were considered to vary from 0 to $10,000 \mathrm{MPa}$ which are equivalent to the ratio of $f_{c u} / f_{c o}$ between 1 to more than 7 . It can be observed that increasing the value of $E_{2}$ leads to the reduction of $n$ as shown in Fig. 9.

Figure 10 shows the effects of changing $f_{o}$ on the value of $n$ with fixed values of $E_{1}$ and $E_{2}$. It is clear that reducing the value of $f_{o}$ leads to the increase of the value of $n$ in order to have the ascending part of the confined stress-strain curve the same as the ascending part of the unconfined concrete. The values of $f_{o}$ was varied between 20 to $150 \mathrm{MPa}$ (Fig. 11).

The relationship between the different parameters and the value of $n$ are drawn in Fig. 12, based on the parametric study discussed above. A regression analysis was performed to propose an equation 
to estimate the value of $n$. The proposed equation (Eq. 22) can estimate the value of $n$ in such a way that the ascending part of the confined concrete stress-strain curve within the elastic range is the same as the ascending part of unconfined concrete (refer to Fig. 4).

$$
\begin{gathered}
n=0.4 e^{0.35 x} \\
x=\frac{E_{1}-E_{2}}{f_{o}^{0.45}} \times 10^{-3}
\end{gathered}
$$

where the units of $E_{1}, E_{2}$ and $f_{o}$ are in $\mathrm{MPa}$

\subsection{Verification of the analytical results}

The axial load-axial deformation behaviour of each component of the GFRP-RC columns was drawn in Fig. 13 based on the stress-strain behaviour presented in Section 4. An Excel spreadsheet was used to perform the calculations and drawing of the axial load-axial deformation behaviour of the specimens. The axial load of a specimen at any axial deformation can be calculated using Eq. (24).

$$
P_{\text {specimen }}=f_{f b} A_{\text {bar }}+f_{c, \text { core }} A_{\text {core }}+f_{c, \text { cover }} A_{\text {cover }}
$$

where $P_{\text {specimen }}$ is the total load of the specimens; $f_{f b}, f_{c, \text { core }}$ and $f_{c, \text { cover }}$ are the axial stresses in the longitudinal GFRP bars, the concrete core and the concrete cover, respectively; and $A_{\text {bar }}, A_{\text {core }}$ and $A_{\text {cover }}$ are the areas of the longitudinal bars, the concrete core and the concrete cover, respectively. Table 4 reports the experimental and calculated confined concrete strength of the specimens. Also, Fig. 14 shows comparisons between the experimental and analytical axial loadaxial deformation behaviour of the tested specimens. The analytical axial load-axial deformation curve of the specimens consisted of the superposition of the axial load-axial deformation of the different components (longitudinal bars, confined concrete core and unconfined concrete cover) of the specimens. A reasonable agreement can be observed between the experimental and analytical axial load-axial deformation behaviours particularly at the ascending part until the first peak load. 
This is because the behaviour of the load-deformation curve of the different components of the specimens at the ascending part was relatively linear until the first peak load. The estimated value of $n$ governed the transition curve between the first and second ascending parts of the axial loadaxial deformation behaviour reasonably close to the experimental results. Also, it can be seen that the second peak load of the axial load-axial deformation behaviour of the experimental results have close agreement with the analytical results. This close agreement essentially means that the developed analytical model calculated confined concrete strength and the corresponding axial strain in reasonable agreement the experimental results.

\section{Conclusions}

In this study, a total of five circular column specimens were tested under concentric axial loads. The specimens were reinforced either with GFRP bars and GFRP helices or only with GFRP helices. Also, one specimen was externally confined with CFRP sheets. The effects of reducing the spacing of the GFRP helices and externally confining the specimen with CFRP sheet were investigated. An analytical model has been developed for the axial load-axial deformation behaviour of circular concrete columns reinforced with GFRP bars and helices. Based on the experimental and analytical investigations carried out in this study, the following conclusions are drawn:

1. Longitudinal GFRP bars improved the first and second peak loads, the ductility and the confined concrete strength of the GFRP-RC specimens because the longitudinal bars reduced the area of unconfined concrete core and increased the hoop strain in the confining materials particularly for the specimens with large spacing of GFRP helices.

2. Reducing the spacing of the GFRP helices or confining the specimens with CFRP sheets enhanced the performance of the specimens in terms of the first and second peak loads, the ductility and the confined concrete strength by providing more lateral confinement pressure and increasing the confined concrete core area. 
3. A parametric study was undertaken to propose an equation for the axial load-axial deformation curve-shape parameter $(n)$. The proposed equation can estimate the value of $n$ in such a way that the ascending part of the confined concrete stress-strain curve is the same as the ascending part of the stress-strain curve of unconfined concrete.

4. The analytical axial load-axial deformation behaviour of the GFRP-RC column specimens was drawn by the superposition of the load-deformation behaviour of the different components (longitudinal GFRP bars, confined concrete core and unconfined concrete cover) of the specimens. The analytical and experimental load-deformation curves agree reasonably well.

\section{Acknowledgments}

The authors thank the University of Wollongong and technical officers at the High Bay laboratory, especially Mr. Fernando Escribano and Mr. Ritchie Mclean for their help in the experimental program of this study. Also, the first author thanks Kurdistan Regional Government of Iraq and University of Wollongong for supporting his Ph.D. scholarship.

\section{References}

[1] Bank L C. Composites for construction: Structural design with FRP materials. Hoboken, New Jersey: John Wiley \& Sons; 2006.

[2] Hollaway L C. The evolution of and the way forward for advanced polymer composites in the civil infrastructure. Constr. Build. Mater. 2003; 176-7: 365-378.

[3] Sheikh M N and Légeron F. Performance based seismic assessment of bridges designed according to Canadian Highway Bridge Design Code. Can. J. Civ. Eng. 2014; 41(9): 777-787.

[4] Manning D G. Corrosion performance of epoxy-coated reinforcing steel: North American experience. Construction and Building Materials 1996; 105 SPEC. ISS.: 349-365. 
[5] Chess P M and Broomfield J P. Cathodic protection of steel in concrete. CRC Press; 2003.

[6] Castro H, Rodriguez C, Belzunce F J, Canteli A F. Mechanical properties and corrosion behaviour of stainless steel reinforcing bars. Journal of Materials Processing Technology 2003; 143-1441: 134-137.

[7] Bellezze T, Malavolta M, Quaranta A, Ruffini N, Roventi G. Corrosion behaviour in concrete of three differently galvanized steel bars. Cement and Concrete Composites 2006; 283: 246255.

[8] Sagüés A A, Lee J B, Chang X, Pickering H, Nystrom E, Carpenter W, et al., "Corrosion of epoxy coated rebar in Florida bridges,"Final Report to Florida DOT WPI, University of South Florida, Tampa, Florida1994.

[9] Xi Y, Abu-Hejleh N, Asiz A, Suwito A, "Performance evaluation of various corrosion protection systems of bridges in Colorado,"Colorado Department of Transportation2004.

[10] Tobbi H, Farghaly A S, Benmokrane B. Behavior of Concentrically Loaded Fiber-Reinforced Polymer Reinforced Concrete Columns with Varying Reinforcement Types and Ratios. ACI Struct. J. 2014; 1112:

[11] Chaallal O and Benmokrane B. Physical and mechanical performance of an innovative glassfiber-reinforced plastic rod for concrete and grouted anchorages. Can. J. Civ. Eng. 1993; 20(2): 254-268.

[12] Benmokrane B, Chaallal O, Masmoudi R. Glass fibre reinforced plastic (GFRP) rebars for concrete structures. Constr. Build. Mater. 1995; 9(6): 353-364.

[13] Alsayed S, Al-Salloum Y, Almusallam T, Amjad M. Concrete columns reinforced by glass fiber reinforced polymer rods. In: Proc., 4th Int. Symp. on Fiber-Reinforced Polymer Reinforcement for Reinforced Concrete Structures, SP-188. Farmington Hills, MI; 1999: 103112. 
[14] De Luca A, Matta F, Nanni A. Behavior of full-scale glass fiber-reinforced polymer reinforced concrete columns under axial load. ACI Struct. J. 2010; 107(5): 589-596.

[15] Tobbi H, Farghaly A S, Benmokrane B. Concrete columns reinforced longitudinally and transversally with glass fiber-reinforced polymer bars. ACI Struct. J. 2012; 109(4): 551-558.

[16] Afifi M Z, Mohamed H M, Benmokrane B. Axial Capacity of Circular Concrete Columns Reinforced with GFRP Bars and Spirals. J. Compos. Constr. 2014; 10.1061/(ASCE)CC.1943$5614.0000438,04013017$.

[17] Afifi M Z, Mohamed H M, Benmokrane B. Strength and Axial Behavior of Circular Concrete Columns Reinforced with CFRP Bars and Spirals. J. Compos. Constr. 2014; 10.1061/(ASCE)CC.1943-5614.0000430, 04013035.

[18] Mohamed H M, Afifi M Z, Benmokrane B. Performance evaluation of concrete columns reinforced longitudinally with FRP bars and confined with FRP hoops and spirals under axial load. J. Bridge Eng. 2014; 10.1061/(ASCE)BE.1943-5592.0000590, 04014020.

[19] Hadi M. Behaviour of wrapped HSC columns under eccentric loads. Asian J. Civil Eng. (Build. Hous.) 2003; 4(2-4): 91-100.

[20] Hadi M N S. Behaviour of FRP wrapped normal strength concrete columns under eccentric loading. Compos. Struct. 2006; 72(4): 503-511.

[21] Hadi M N S. Comparative study of eccentrically loaded FRP wrapped columns. Compos. Struct. 2006; 74(2): 127-135.

[22] Hadi M N S. The behaviour of FRP wrapped HSC columns under different eccentric loads. Compos. Struct. 2007; 78(4): 560-566.

[23] Hadi M N S. Behaviour of FRP strengthened concrete columns under eccentric compression loading. Compos. Struct. 2007; 77(1): 92-96.

[24] Hadi M N S. Behaviour of eccentric loading of FRP confined fibre steel reinforced concrete columns. Constr. Build. Mater. 2009; 23(2): 1102-1108. 
[25] Hadi M N S. Behaviour of reinforced concrete columns wrapped with fibre reinforced polymer under eccentric loads. Aust. J. Struct. Eng. 2010; 10(2): 169-178.

[26] Hadi M N S and Widiarsa I B R. Axial and flexural performance of square RC columns wrapped with CFRP under eccentric loading. J. Compo. Constr. 2012; 10.1061/(ASCE)CC.1943-5614.0000301, 16:640-649.

[27] Hadi M N S, Pham T M, Lei X. New method of strengthening reinforced concrete square columns by circularizing and wrapping with fiber-reinforced polymer or steel straps. J. Compos. Constr. 2013; 10.1061/(ASCE)CC.1943-5614.0000335, 17:229-238.

[28] Hadi M N S and Le T D. Behaviour of hollow core square reinforced concrete columns wrapped with CFRP with different fibre orientations. Constr. Build. Mater. 2014; 50: 62-73.

[29] Hadi M N S, Wang W, Sheikh M N. Axial compressive behaviour of GFRP tube reinforced concrete columns. Constr. Build. Mater. 2015; 81: 198-207.

[30] Tobbi H, Farghaly A S, Benmokrane B. Strength model for concrete columns reinforced with fiber-reinforced polymer bars and ties. ACI Structural Journal 2014; 1114: 789-798.

[31] V-Rod Australia. Composite reinforcing rods technical data sheet. Largs Bay SA, Australia; 2012.

[32] AS 1012.9-1999. Determination of the compressive strength of concrete specimens. Sydney, NSW: Australian Standard; 1999.

[33] ASTM D7205/D7205M-11. Standard test method for tensile properties of fiber reinforced polymer matrix composite bars. West Conshohocken, PA: American Society for Testing and Materials; 2011.

[34] ASTM D7565/D7565M-10. Standard Test Method for Determining Tensile Properties of Fiber Reinforced Polymer Matrix Composites Used for Strengthening of Civil Structures. West Conshohocken, PA: American Society for Testing and Materials; 2010. 
[35] Sheikh M N, Tsang H H, McCarthy T J, Lam N T K. Yield curvature for seismic design of circular reinforced concrete columns. Mag. Concr. Res. 2010; 62(10): 741-748.

[36] Gunes O, Lau D, Tuakta C, Büyüköztürk O. Ductility of FRP-concrete systems: Investigations at different length scales. Construction and Building Materials 2013; 49: 915925.

[37] Yang K H, Mun J H, Cho M S, Kang T H K. Stress-strain model for various unconfined concretes in compression. ACI Struct. J. 2014; 111(4): 819-826.

[38] ACI 318-14. Building code requirements for structural concrete. Farmington Hills, MI: American Concrete Institute; 2014.

[39] Légeron F. Seismic behavior of structures made with normal and high-performance concrete. $\mathrm{PhD}$ thesis, Univ. of Sherbrooke and École Nationale de Ponts et Chaussés, Sherbrooke, and Paris (in French); 1998.

[40] Karim H, Sheikh M N, Hadi M N S. Confinement of Circular Concrete Columns: A Review. In: Proc. 1st Int. Eng. Conf., Developments in Civil \& Computer Engineering Applications (IEC2014). Ishik University, Erbil, KRG, Iraq; 2014: 28-36.

[41] ACI 440.2R-08. Guide for the Design and Construction of Externally Bonded FRP Systems for Strengthening Concrete Structures. Framington, MI: American Concrete Institute; 2008.

[42] Bisby L, Take W, Caspary A. Quantifying strain variation in FRP confined concrete using digital image correlation: Proof-of-concept and initial results. In: Asia-Pacific conference on FRP in structures (APFIS 2007). Dept of Civil Eng. Queen's University, Canada; 2007.

[43] Bisby L and Ranger M. Axial-flexural interaction in circular FRP-confined reinforced concrete columns. Constr. Build. Mater. 2010; 24(9): 1672-1681.

[44] Ozbakkaloglu T and Lim J C. Axial compressive behavior of FRP-confined concrete: Experimental test database and a new design-oriented model. Composites Part B: Engineering $2013 ; 55$ 607-634. 
[45] Ahmed E A, El-Sayed A K, El-Salakawy E, Benmokrane B. Bend strength of FRP stirrups: Comparison and evaluation of testing methods. J. Compos. Constr. 2010; 10.1061/(ASCE)CC.1943-5614.0000050, 14:3-10.

[46] ACI 440.1R-15. Guide for the design and construction of concrete reinforced with FRP bars. Farmington Hills, MI: American Concrete Institute; 2015.

[47] Lee J Y, Yi C K, Jeong H S, Kim S W, Kim J K. Compressive Response of Concrete Confined with Steel Spirals and FRP Composites. J. Compos. Mater. 2010; 44(4): 481-504.

[48] $\mathrm{Hu} \mathrm{H}$ and Seracino R. Analytical model for FRP-and-steel-confined circular concrete columns in compression. J. Compos. Constr. 2014; 10.1061/(ASCE)CC.1943-5614.0000394, A4013012.

[49] Shirmohammadi F, Esmaeily A, Kiaeipour Z. Stress-strain model for circular concrete columns confined by FRP and conventional lateral steel. Eng. Struct. 2015; 84: 395-405.

[50] Samaan M, Mirmiran A, Shahawy M. Model of concrete confined by fiber composites. J. Struct. Eng. 1998; 124(9): 1025-1031.

[51] Jaejer L, Mufti A, Tadros G. The concept of the overall performance factor in rectangularsection reinforced concrete beams. In: Proceedings of the 3rd International Symposium on Non-Metallic (FRP) Reinforcement for Concrete Structures; 1997: 551-558. 


\section{List of Tables}

Table 1. Test Matrix

Table 2. Mechanical properties of steel and GFRP bars and CFRP sheet

Table 3. Experimental results

Table 4. Experimental and analytical confined concrete strength 


\section{List of Figures}

Fig. 1. Failure modes of the tested columns

Fig. 2. Axial load-axial deformation behaviour of the tested specimens

Fig. 3. Confining mechanism for concrete confined by GFRP helices and CFRP sheets

Fig. 4. Comparison between existing and proposed $n$ value

Fig. 5. Flowchart for numerically solving value of $n$

Fig. 6. Influence of $E_{1}$ on stress-strain behaviour

Fig. 7. Influence of $E_{1}$ on $n$

Fig. 8. Influence of $E_{2}$ on stress-strain behaviour

Fig. 9. Influence $E_{2}$ on $n$

Fig. 10. Influence of $f_{o}$ on stress-strain behaviour

Fig. 11. Influence of $f_{o}$ on $n$

Fig. 12. Relationship between $E_{1}, E_{2}$ and $f_{o}$ with $n$

Fig. 13. Analytical axial load-axial deformation behaviour of different components of the specimens

Fig. 14. Comparison between experimental and analytical axial load-axial deformation behaviour of the tested columns; (a) G6-G60; (b) G6-G60; (c) 00-G60; (d) 00-G30; (e) CG6-G60 
Table 1. Test Matrix

\begin{tabular}{|c|c|c|c|c|c|}
\hline \multirow{2}{*}{ Specimen } & \multicolumn{2}{|c|}{ Longitudinal reinforcement } & \multicolumn{2}{c|}{ Transverse reinforcement } & \multirow{2}{*}{ Confinement } \\
\cline { 2 - 6 } & Diameter & Number & Diameter & Spacing \\
$(\mathrm{mm})$ & & $(\mathrm{mm})$ & 60 & \\
\hline G6-G60 & 12.7 & 6 & 9.5 & 30 & - \\
\hline G6-G30 & 12.7 & 6 & 9.5 & 60 & - \\
\hline 00-G60 & - & - & 9.5 & 30 & - \\
\hline 00-G30 & - & - & 9.5 & 60 & CFRP sheet \\
\hline CG6-G60 & 12.7 & 6 & 9.5 & & \\
\hline
\end{tabular}


Table 2. Mechanical properties of steel and GFRP bars and CFRP sheet

\begin{tabular}{|c|c|c|c|c|}
\hline Material & $\begin{array}{c}\text { Diameter } \\
(\mathrm{mm})\end{array}$ & $\begin{array}{c}\text { Ultimate tensile } \\
\text { strength } \\
(\mathrm{MPa})\end{array}$ & $\begin{array}{c}\text { Elastic tensile } \\
\text { modulus } \\
(\mathrm{GPa})\end{array}$ & $\begin{array}{c}\text { Strain corresponding to } \\
\text { ultimate tensile strength } \\
(\mathrm{mm} / \mathrm{mm})\end{array}$ \\
\hline GFRP \#4 & 12.7 & 1600 & 66 & 0.0242 \\
\hline GFRP \#3 & 9.5 & 1700 & 76 & 0.0224 \\
\hline
\end{tabular}


Table 3. Experimental results

\begin{tabular}{|c|c|c|c|c|c|}
\hline \multirow{2}{*}{ Specimen } & \multicolumn{2}{|c|}{ First peak } & \multicolumn{2}{c|}{ Second peak } & \multirow{2}{*}{ Ductility } \\
\cline { 2 - 5 } & Load & Deformation & Load & Deformation & ( \\
& $(\mathrm{kN})$ & $(\mathrm{mm})$ & $(\mathrm{kN})$ & 5.15 & 3.2 \\
\hline G6-G60 & 1220 & 1.60 & 1425 & 7.60 & 4.9 \\
\hline G6-G30 & 1309 & 1.56 & 2041 & $3.20^{\mathrm{a}}$ & 2.3 \\
\hline 00-G60 & 1063 & 1.40 & 940 & 6.52 & 4.8 \\
\hline 00-G30 & 1170 & 1.35 & 1343 & 8.18 & 6.6 \\
\hline CG6-G60 & $1320^{\mathrm{b}}$ & $1.24^{\mathrm{b}}$ & 3068 & & \\
\hline
\end{tabular}

${ }^{\mathrm{a}}$ Corresponding to $80 \%$ of the first peak load in the descending part

${ }^{\mathrm{b}}$ Corresponding to the transition point between the first and second ascending part 
Table 4. Experimental and analytical confined concrete strength

\begin{tabular}{|c|c|c|c|c|}
\hline \multirow{2}{*}{ Specimen } & \multicolumn{2}{|c|}{ Load carried by the bars (kN) } & \multicolumn{2}{c|}{ Confined concrete strength (MPa) } \\
\cline { 2 - 5 } & First peak & Second peak & Experimental & Analytical \\
\hline G6-G60 & 148 & 307 & 55.6 & 55.5 \\
\hline G6-G30 & 138 & 494 & 76.9 & 75.8 \\
\hline 00-G60 & - & - & 46.8 & 49.8 \\
\hline 00-G30 & - & - & 66.8 & 66.1 \\
\hline CG6-G60 & - & 593 & 75.8 & 76.1 \\
\hline
\end{tabular}




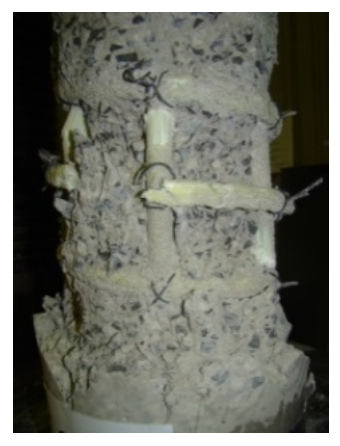

G6-G60

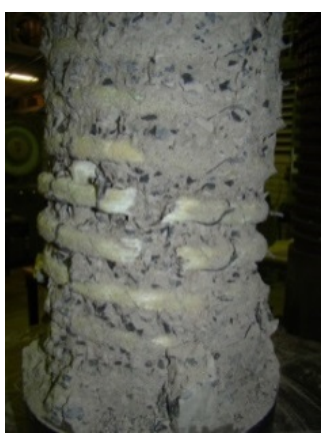

G6-G30

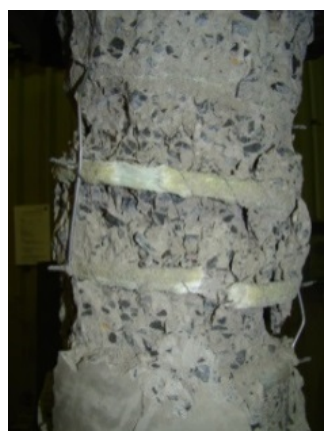

00-G60

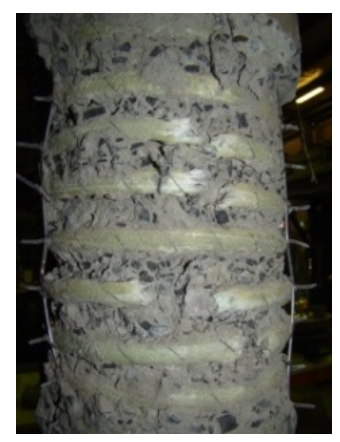

00-G30

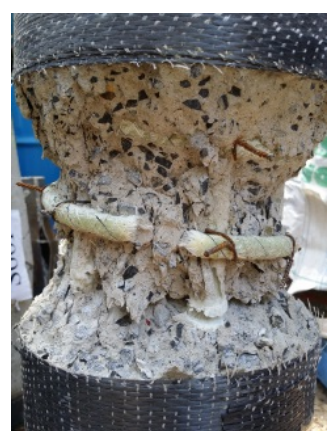

CG6-G60

Fig. 1. Failure modes of the tested columns 


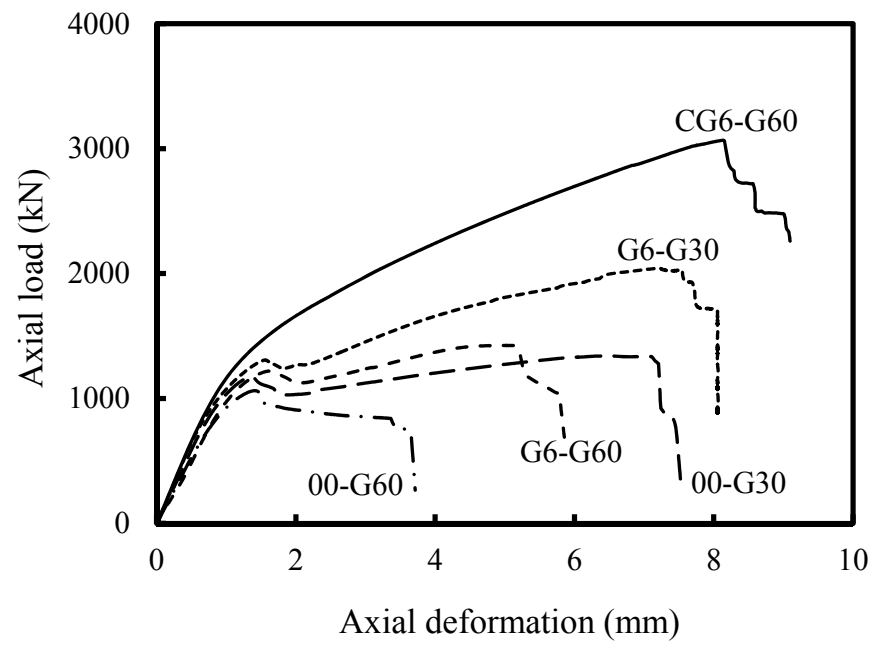

Fig. 2. Axial load-axial deformation behaviour of the tested specimens 


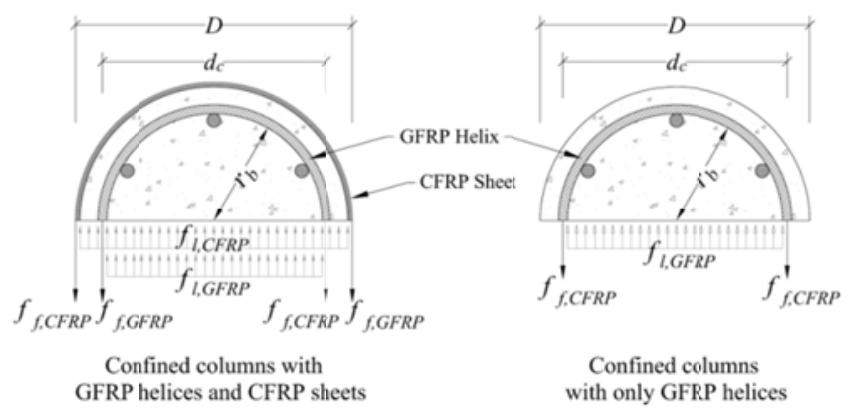

Fig. 3. Confining mechanism for concrete confined by GFRP helices and CFRP sheet 


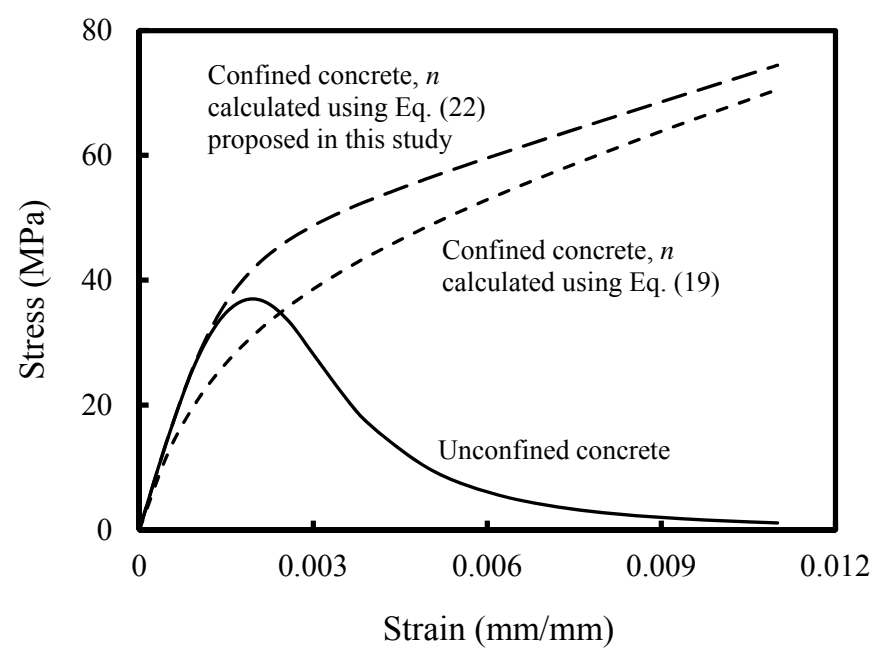

Fig. 4. Comparison between existing and proposed $n$ value 


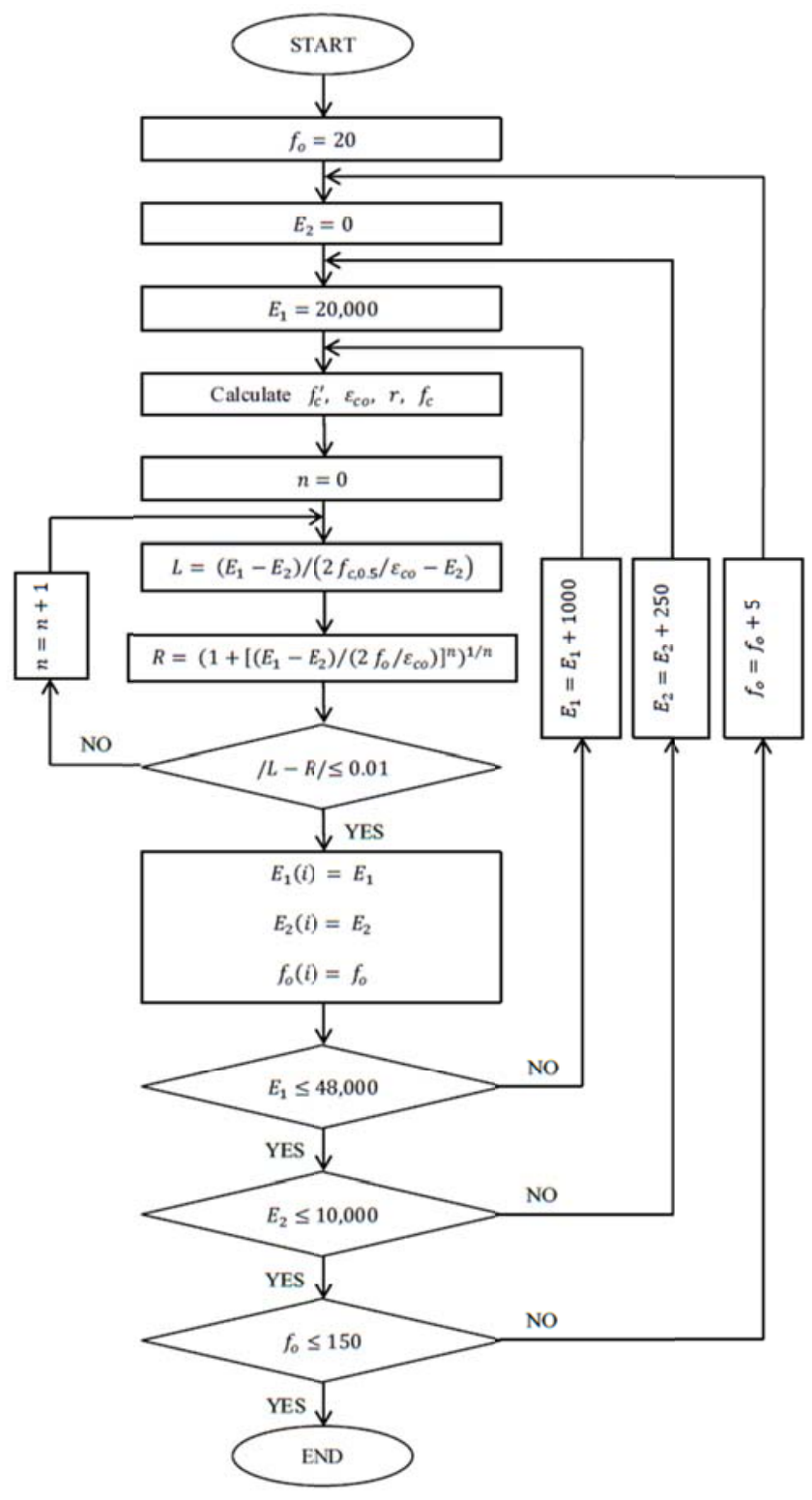

Fig. 5. Flowchart for numerically solving value of $n$ 


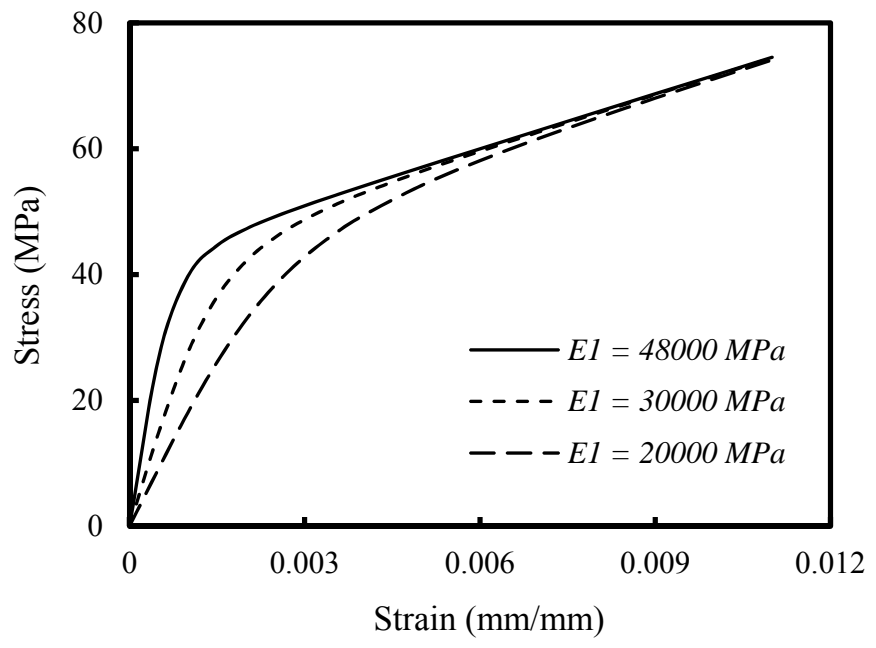

Fig. 6. Influence of $E_{1}$ on stress-strain behaviour 


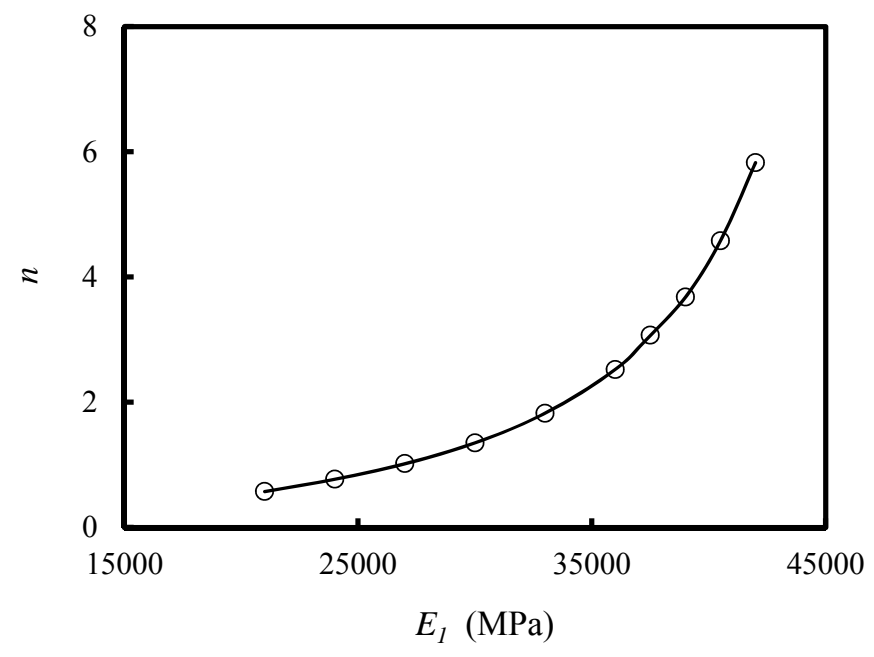

Fig. 7. Influence of $E_{1}$ on $n$ 


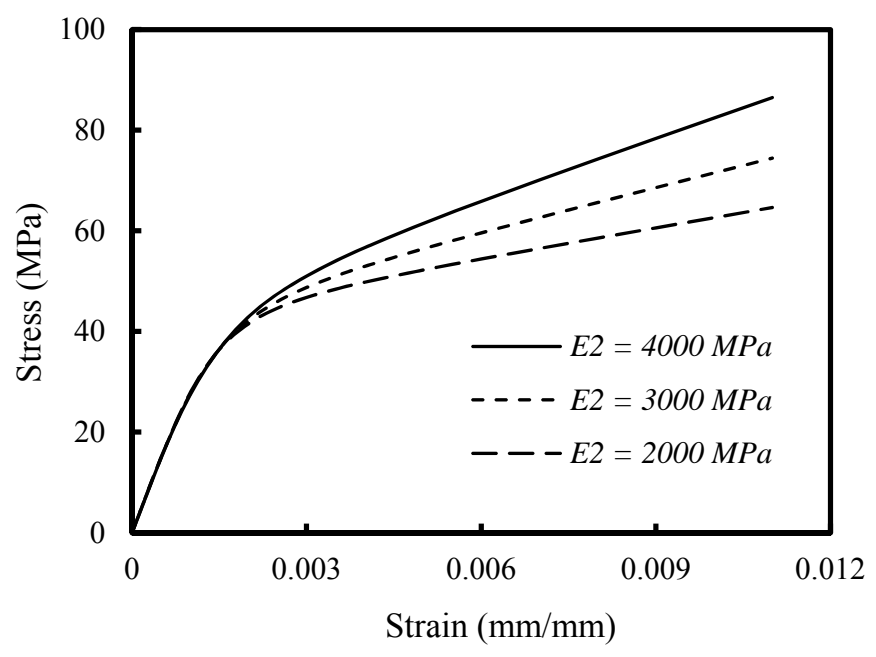

Fig. 8. Influence of $E_{2}$ on stress-strain behaviour 


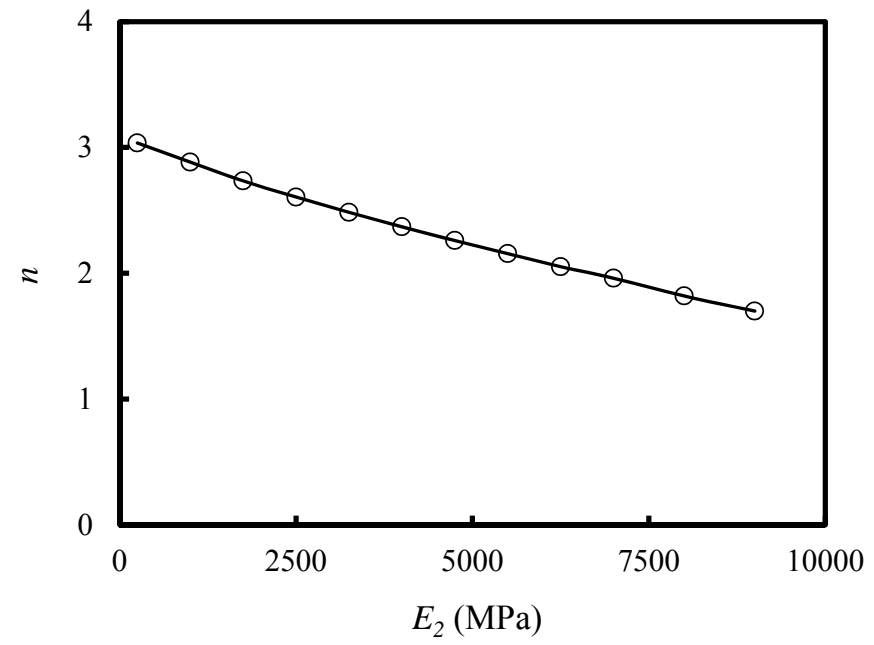

Fig. 9. Influence of $E_{2}$ on $n$ 


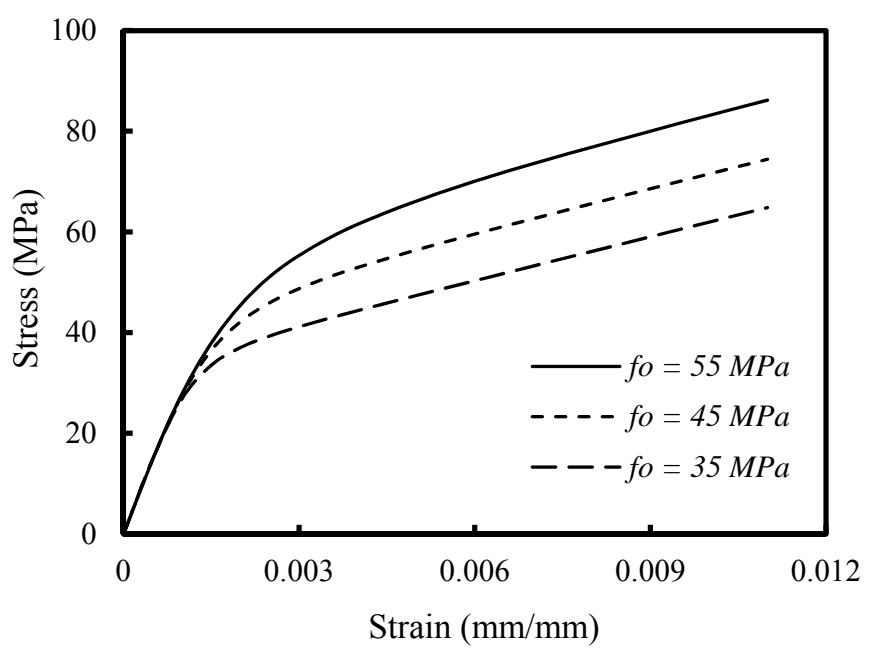

Fig. 10. Influence of $f_{o}$ on stress-strain behaviour 


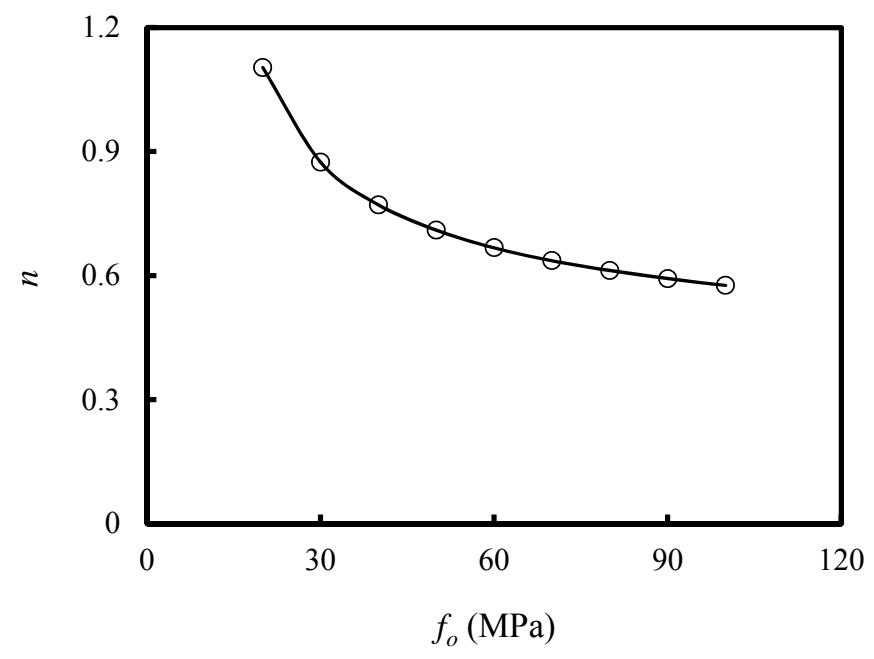

Fig. 11. Influence of $f_{o}$ on $n$ 


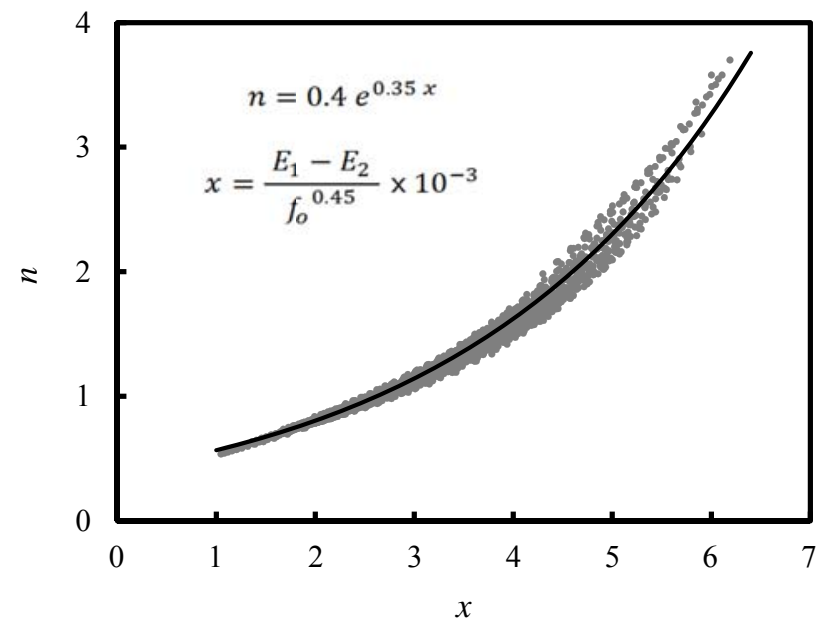

Fig. 12. Relationship between $E_{1}, E_{2}$ and $f_{o}$ with $n$ 


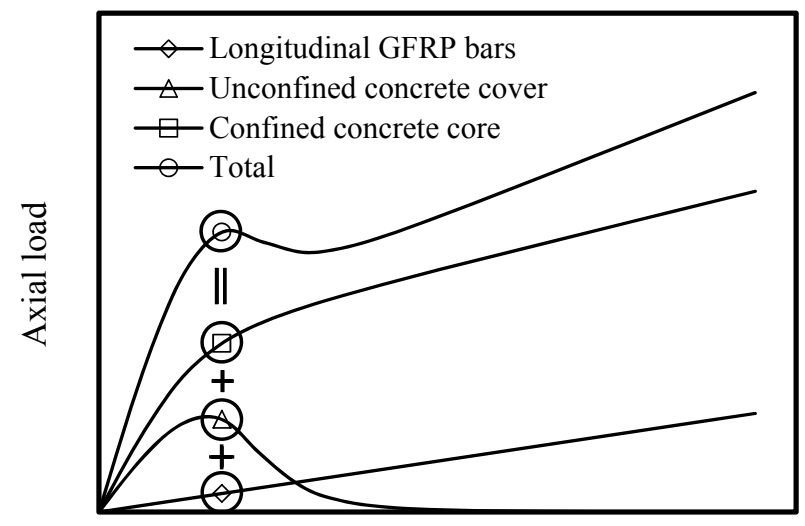

Axial deformation

Fig. 13. Analytical axial load-axial deformation behaviour of different components of the specimens 


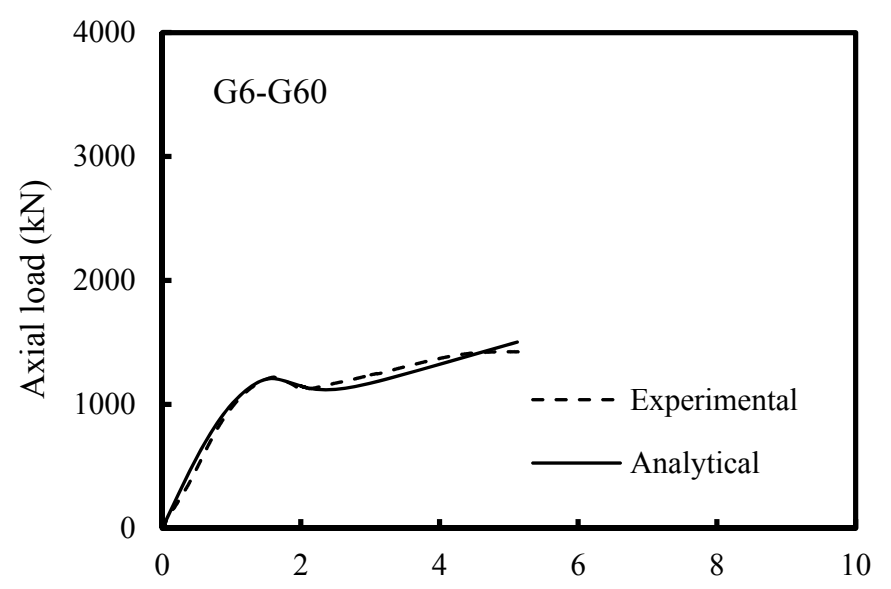

(a)

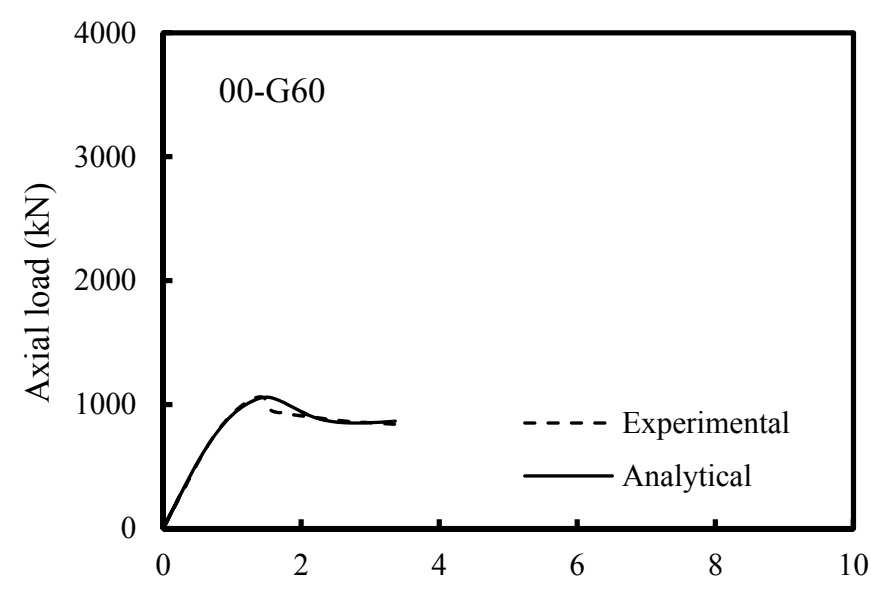

(c)

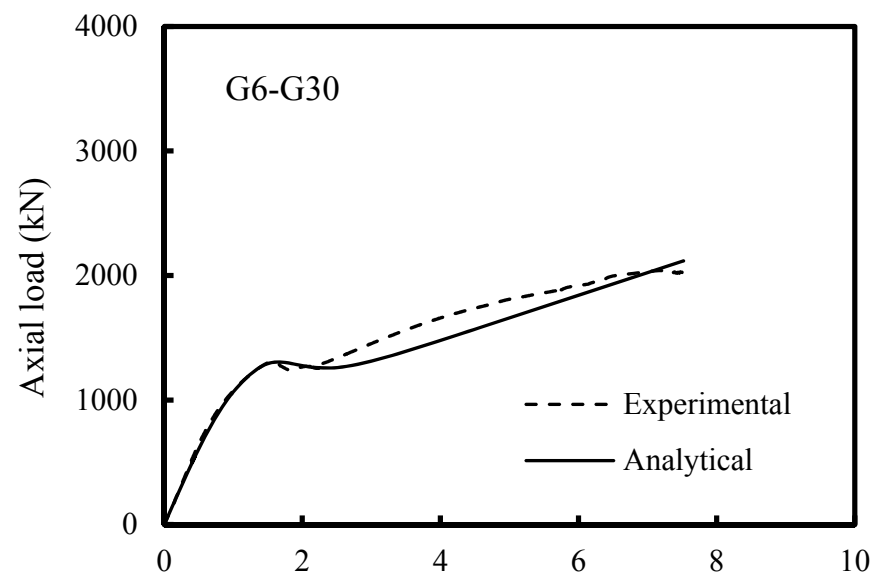

(b)

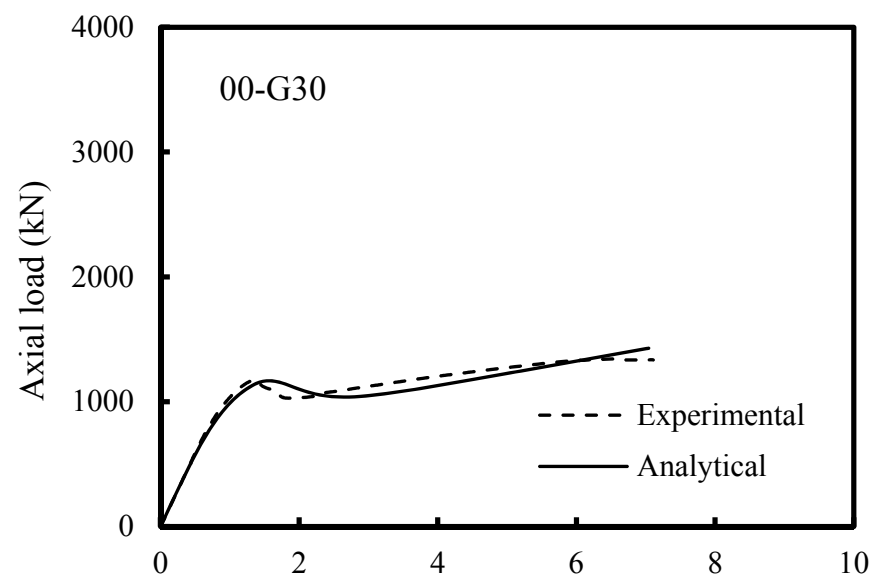

(d) Axial deformation (mm)

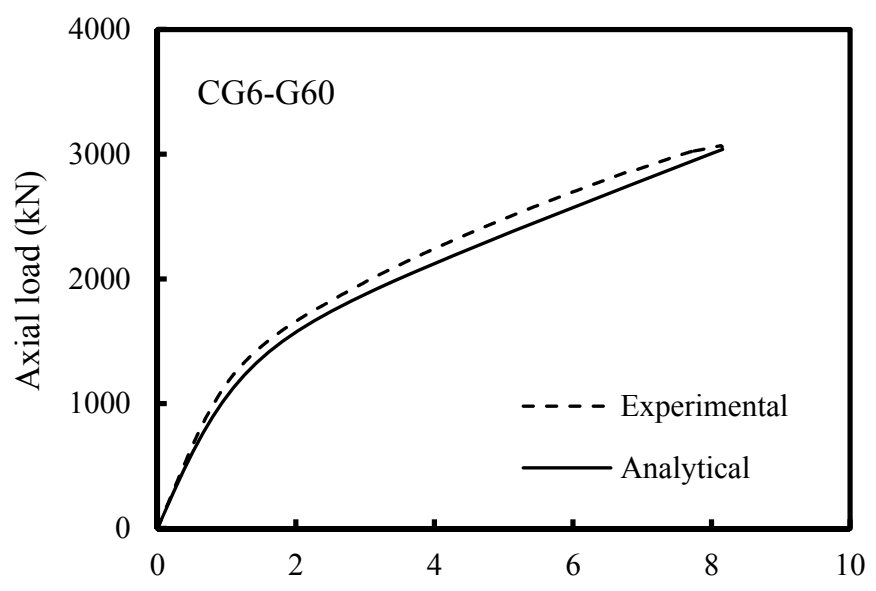

(e) Axial deformation (mm)

Fig. 14. Comparison between experimental and analytical axial load-axial deformation behaviour of the tested columns; (a) G6-G60; (b) G6-G60; (c) 00-G60; (d) 00-G30; (e) CG6-G60 